\title{
Mapping the Wind Energy Potential of Sweden: A Sociotechnical Wind Atlas
}

\author{
Peter Enevoldsen (D) ${ }^{1}$ and Finn-Hendrik Permien ${ }^{2,3}$ \\ ${ }^{1}$ Centre for Energy Technologies, Aarhus University, Denmark \\ ${ }^{2}$ BTECH, Aarhus University, Denmark \\ ${ }^{3}$ Siemens Gamesa Renewable Energy, Spain \\ Correspondence should be addressed to Peter Enevoldsen; peterenevoldsen@btech.au.dk
}

Received 7 March 2018; Revised 4 June 2018; Accepted 6 June 2018; Published 9 July 2018

Academic Editor: Shuhui Li

Copyright @ 2018 Peter Enevoldsen and Finn-Hendrik Permien. This is an open access article distributed under the Creative Commons Attribution License, which permits unrestricted use, distribution, and reproduction in any medium, provided the original work is properly cited.

\begin{abstract}
The installation of onshore wind farms has increased in the past decade all over Sweden, and as a result, more wind projects are facing challenges of, for instance, social opposition and lack of space, which potentially complicate resource assessments. As a response to the current challenges in the Swedish wind industry, this study examines and develops a strategic map of potential areas for the construction of new farms in Sweden. The analyses used to prepare the map are performed using a holistic research strategy that focuses on everything from social to technical challenges. The map is based on an extensive data collection consisting of a comprehensive wind dataset mixed with the outcome of large-scale qualitative studies that include five dominant stakeholder groups in the Swedish wind industry and detailed information on restrictive areas. Consequently, this research presents a resource map, which is intended to inspire all stakeholders in the Swedish wind industry to further develop the successful case of wind power in Sweden. Furthermore, the current research aims to update ongoing debates in the wind energy literature, and finally, it introduces a tool that can be used in all phases of a large-scale energy strategy that involves wind power.
\end{abstract}

\section{Introduction}

Wind power has become the most important technology in the renewable energy transition, which every year is confirmed by the increasing number of wind turbines, employees in the wind industry [1], new countries interacting [2], supporting policies, and most importantly the installed energy capacity. The development in Sweden is not different than the one observed globally, and as the graphs in Figure 1 reveal, the annual development of installed wind power capacity in Sweden, in terms of the annual percentage increase, was actually more explosive than the 2006-2017 global development.

The past decade's positive development in installed wind capacity in Sweden was ensured by the establishment and renewal of the green certificate schemes in 2003 and 2006, respectively [3]. This additional financial benefit to the market price for green electricity invited the large wind project developers and investors to focus on the Swedish market
$[4,5]$, and as a result, the Swedish installed capacity (MW) increased from $509 \mathrm{MW}$ at the end of 2005 to $6519 \mathrm{MW}$ at the of 2016 [4]. The national energy policy has in many cases been the most important parameter for the promotion of wind power [5], and compared to its Danish neighbors, Sweden entered the wind market much later, mainly due to the fact that its energy policy did not focus on wind as a solution to the oil crisis in the 1970s [6]. The late entrance is one of the main reasons why the majority of Swedish wind power is based on multimegawatt wind turbines. The CAPEX costs of these types of wind turbines are higher than for the ones introduced in the pioneer stage in Denmark, which has been to the detriment of potential local private investments and instead paved the way for large investment organizations. A previous study has determined that local private investments are a key factor in improving the social acceptance of new wind project development [7]. In combination with a decentralized political system [8], this produces a unfortunate situation that allows the Swedish municipalities and local inhabitants to 


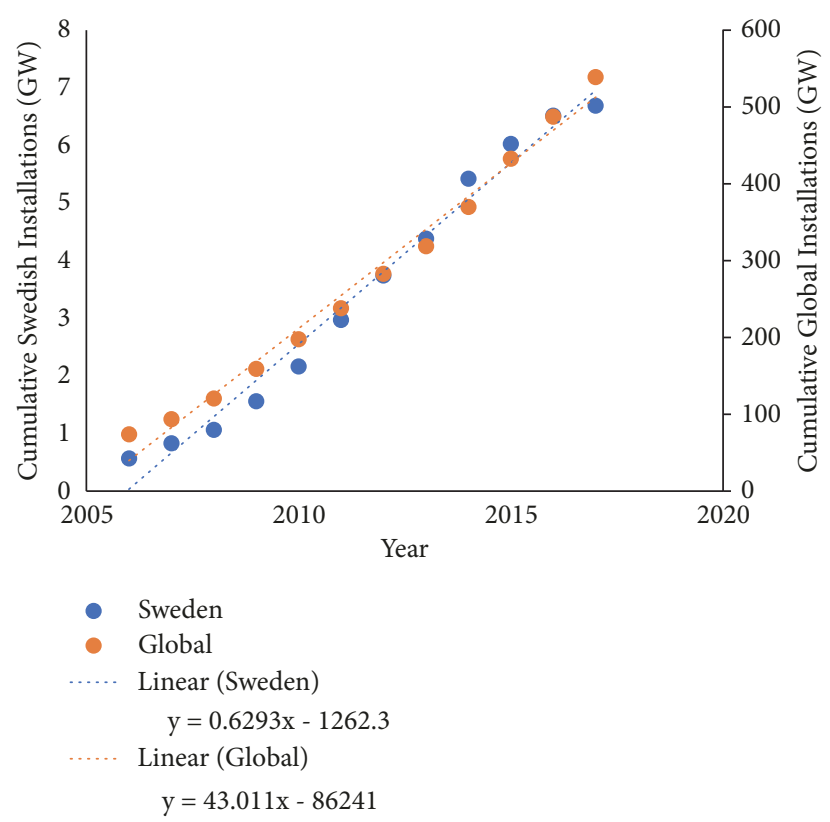

Figure 1: The annual development of installed wind capacity in Sweden versus the world.

turn down wind projects, an outcome that has been targeted and proven by previous studies $[9,10]$. The recent decline in annual growth presented in Figure 1 additionally raises concerns about the future development of wind power in Sweden.

1.1. Addressing the Risks. The increasing social opposition can be seen as a direct response to Sweden's energy policy of almost five decades. In 2014, Ek \& Persson [10] analyzed the results of a large study which involved the opinions of 1,500 respondents and a sample from a web panel of 90,000 Swedes. The results revealed a majority of support for wind power. Yet people prefer offshore wind power, and studies have shown that Swedes are even willing to pay a higher price for electricity, if the wind turbines are deployed away from recreational areas, without harming avian and local animal life, however [11]. Just as interesting, the quantitative study revealed that the Swedes want to have the opportunity to invest in new wind farms and to be involved in the planning process [10]; both of these opportunities, if lacking, are in alignment with synthetic reasons for social opposition [7]. Swedish studies have furthermore investigated the local benefits of installing wind power in rural areas of Sweden, which can be seen as a reaction to the challenges [12] that wind project developers are facing in those parts of the country. The complications of social opposition resulting from the late introduction of wind power as well as an energy policy favoring large-scale investments while having a decentralized political system for the approval of prospective wind farms entail that Sweden could be seen as a risky place for investors. In addition, a study examining wind turbine risks in Northern Europe determined one of the greatest risks of wind project delays in Sweden to be the public inquires and opposition towards landscape interference [13].
However, another study has suggested that the Swedish opposition is very similar to the one that hydropower, nuclear, and biomass energy encountered when introduced as energy sources in Sweden [14]. In fact, a number of the wind power opponents have become synonymous with supporters of nuclear energy and hydropower, due to the trust of other sources being more environmentally friendly and effective [14]. A study on French energy policy found the same pattern of opposition as an explanation to the challenges of developing wind projects in France [15], for which reason such ideology poses a threat to the continued development of wind power.

The efficiency of onshore Swedish wind projects relies largely on the site and resource assessment, as the majority of Sweden (66\%) is covered by forest [16] and researchers have found that forests present a challenge for predicting wind conditions [13]. This is particularly the case in Sweden, where industrial forestry causes deforestation in structured patterns, which changes the formation of the forest into heterogeneous clusters that lead to continuous changes in the wind conditions above the forest canopy $[17,18]$. In combination with the sociopolitical demands to avoid wind turbine deployment in recreational areas as well as the motivation to interact with the Swedish people in the planning process, a high-resolution wind resource map or atlas consisting of factors that represent the technical challenges and reveal areas with favorable wind conditions will be constructed and discussed in this research. A sociotechnical wind atlas will not only reveal where to avoid challenges for wind farm deployment, but also support the promotion of wind power in Sweden, which is very much needed, as the Swedish government has an ambitious target of making room for $30 \mathrm{TWh} /$ year in Sweden by 2020, of which $10 \mathrm{TWH} /$ year is for offshore wind power [14].

\section{Research Material and Methods}

This section introduces the methods and materials used to collect and analyze data for constructing the sociotechnical wind atlas. The introduction and structure of the data collection in this research are based on a literature search conducted using the search words "wind energy", "wind power", and "wind turbines" in combination with "Sweden" and "onshore", "wind atlas", and "resource assessment" in the Google Scholar and ScienceDirect databases. The total number of papers was enormous, for which reason literature was analyzed until a research design for creating the sociotechnical wind atlas was established. This resulted in a total of 20 papers. As presented in the introduction of the research, the literature review exposed some of the challenges for Sweden's desired wind power expansion, challenges that a sociotechnical wind atlas will help solve.

2.1. Wind Data. The extensive dataset for constructing the wind resource map has been collected through interactions with wind turbine manufacturers and the creators of an existing wind atlas for Sweden. The wind data collected for this research are based on the wind speed measured on more than 430 onshore wind turbines and more than 25 
TABLE 1: Testing the wind atlas.

\begin{tabular}{lcccc}
\hline Wind atlas $(\mathbf{1 0 0} \mathbf{~ m})$ & $\begin{array}{c}\text { Measurement height } \\
\text { ABGL } \mathbf{( m )}\end{array}$ & $\begin{array}{c}\text { Measured wind speed } \\
(\mathbf{m} / \mathbf{s})\end{array}$ & Delta difference (\%) & Delta difference $(\mathbf{m} / \mathbf{s})$ \\
\hline 7.17 & 100 & 7.36 & 2.6 & 0.19 \\
\hline 6.64 & 100 & 7.01 & 5.3 & 0.37 \\
\hline 6.75 & 100 & 7.02 & 3.8 & 0.27 \\
\hline 6.96 & 100 & 7 & 0.6 & 0.04 \\
\hline 7.63 & 100 & 8.1 & 5.8 & 0.47 \\
\hline 7.10 & 100 & 6.3 & 12.7 & 0.80 \\
\hline 6.72 & 94 & 6.31 & 6.5 & 0.41 \\
\hline 6.82 & 99 & 6.29 & 8.4 & 0.53 \\
\hline 6.90 & 98 & 6.7 & 3.0 & 0.20 \\
\hline
\end{tabular}

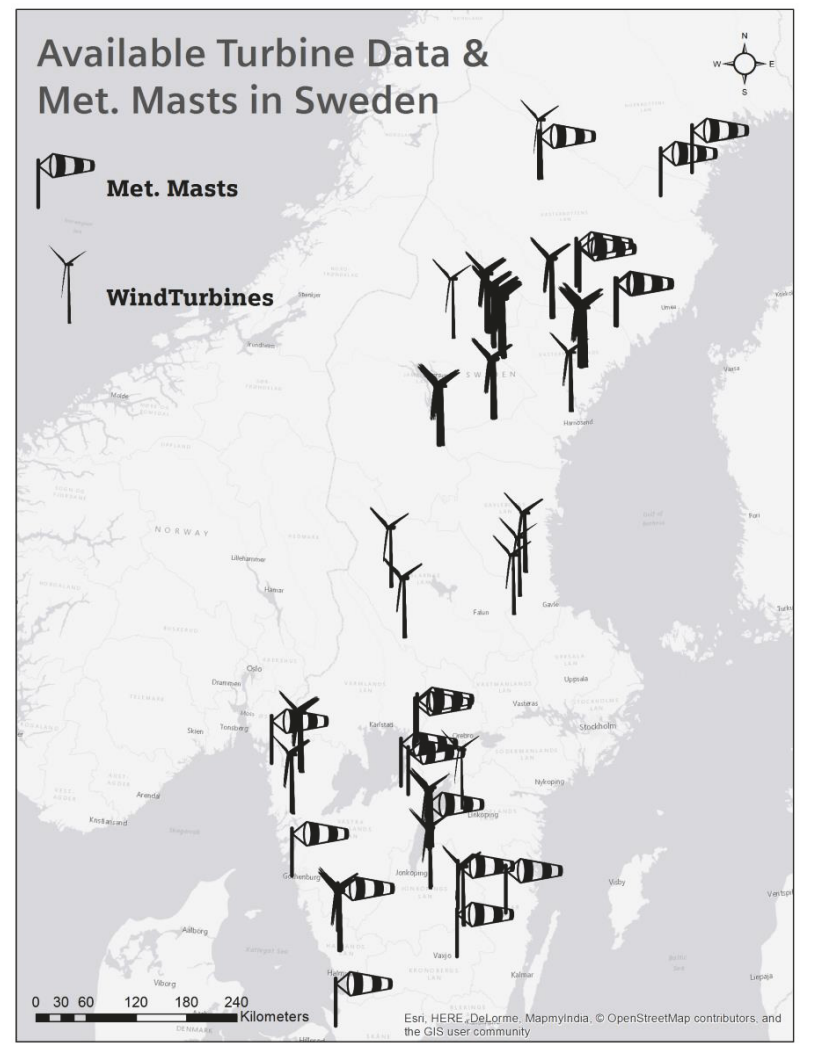

Figure 2: Physical measurement devices.

meteorological masts located all over Sweden. The physical measurements have been coupled with a mesoscale highresolution dataset $(500 \mathrm{~m} \times 500 \mathrm{~m})$ from WeatherTech and implemented in the map following the Voronoi method. Although the position of the physical measurements has been anonymized, Figure 2 gives a rough introduction to the location of the different measurement devices.

As illustrated in Figure 2, the extensive amount of physical measurement devices covers the majority of Sweden, as the gap between Sweden and Norway is dominated by mountains and therefore not appropriate for deployment of wind turbines. Furthermore, despite being a rather novel wind country, Sweden is already covered by different sources of mesoscale dataset for wind conditions, few, however, with data at the hub height of a modern multimegawatt wind turbine (approx. $100 \mathrm{~m}$ ), which is required for siting wind turbines in forested areas. One dataset with estimated wind speeds for such height is the high-resolution mesoscale dataset from WeatherTech. The mesoscale dataset was constructed using the MIUU method developed at Uppsala University in Sweden. A statistical analysis revealed a minor error (a delta difference of 7\%) in the wind speeds predicted at $100 \mathrm{~m}$ above ground level when compared to the measurements from ten meteorological masts, for which reason the dataset from WeatherTech is considered highly reliable for the detection of wind resources in Sweden. The test of the combined wind atlas is presented in Table 1; the positions of the reference meteorological masts, however, have been anonymized.

Nevertheless, Figure 2 shows that the physical measurement locations cover the majority of Sweden. Thus, adding these measurements is considered an improvement of the existing wind atlas from WeatherTech. As shown from Table 1 , this has been confirmed by the absolute mean delta difference of $5.4 \%$ between the measurement masts and the combined wind atlas.

2.2. Qualitative Studies. As stated in the introduction to this research, previous studies have already collected and analyzed quantitative data on the Swedes' perception of future wind farm locations. It has therefore not been necessary to perform a new data collection and make new interpretations, since the novelty and quality of the existing studies easily can be transferred to this research. Nonetheless, one criticism of using the existing studies in this context seems to be the lack of investigating all stakeholders in the Swedish wind industry as well as the stakeholders' perception of developing onshore Swedish wind power. In order to target a broad and representative group of stakeholders, a model following three steps for assessing stakeholders has been used [17]. The three steps are (1) identifying stakeholder groups, (2) screening the stakeholder group members, and (3) analyzing the stakeholders to identify respondents. The 
TABLE 2: The perceived risks for new wind project development in Sweden.

\begin{tabular}{|c|c|c|c|}
\hline Stakeholder groups & Organization & $\begin{array}{c}\text { Greatest risks for new wind project } \\
\text { development in Sweden }\end{array}$ & Other comments \\
\hline Policy & Research institutions & $\begin{array}{l}\text { The Swedish municipal planning } \\
\text { monopoly allows anti-wind organizations } \\
\text { to impact decisions regarding prospected } \\
\text { wind farms. Consequently, due to a lack } \\
\text { of vertical integration, Sweden has a } \\
\text { longer development time frame than the } \\
\text { other Nordic countries. }\end{array}$ & $\begin{array}{l}\text { In Sweden, the social opposition of wind } \\
\text { projects is rarely due to NIMBYism. } \\
\text { Instead, opposition arises due to the wind } \\
\text { turbines' expected impact on the } \\
\text { landscape. As an example, the northern } \\
\text { part of Sweden, which is more rural than } \\
\text { the southern, is facing strong opposition } \\
\text { due to the impact on the landscape. }\end{array}$ \\
\hline Policy & $\begin{array}{l}\text { The Swedish Forest } \\
\text { Agency }\end{array}$ & $\begin{array}{l}\text { Forestry is a very important part of the } \\
\text { Swedish economy, and it is believed that } \\
\text { forestry and wind energy can be } \\
\text { combined to obtain a larger profit from } \\
\text { each forest. }\end{array}$ & $\begin{array}{l}\text { Wind power can add value to industrial } \\
\text { forests. }\end{array}$ \\
\hline Policy/public & Anti-wind organizations & $\begin{array}{l}\text { If the citizens of the municipality are not } \\
\text { involved in the wind project, they are } \\
\text { likely to oppose/protest it. Furthermore, } \\
\text { wind power as an energy source is rated } \\
\text { to have a lower efficiency than } \\
\text { hydropower and nuclear energy. }\end{array}$ & $\begin{array}{l}\text { Wind turbines will destroy nature during } \\
\text { transportation, construction, operation, } \\
\text { and dismantling. }\end{array}$ \\
\hline Wind assessment & Research institutions & $\begin{array}{l}\text { While the wind resource is often } \\
\text { overestimated in forested areas, the loads } \\
\text { on the wind turbines are often } \\
\text { underestimated. Overall, this leads to less } \\
\text { efficient wind turbines. }\end{array}$ & $\begin{array}{l}\text { The meteorological masts are often } \\
\text { located where there is little impact from } \\
\text { the forest in order to represent the best } \\
\text { possible business case. This is a risk in } \\
\text { heterogeneous forests. }\end{array}$ \\
\hline Wind assessment & Wind project developer & $\begin{array}{l}\text { It requires substantial resources to assess } \\
\text { if a forested area is in fact suitable for a } \\
\text { wind project, as studies on animal life } \\
\text { need to be conducted. In addition, it must } \\
\text { be determined whether the area is } \\
\text { protected. }\end{array}$ & $\begin{array}{l}\text { It complicates and increases the } \\
\text { development costs if there is social } \\
\text { opposition against the wind project. }\end{array}$ \\
\hline Public & Swedish citizens & $\begin{array}{l}\text { The height of wind turbines has made it } \\
\text { possible to install them anywhere, and } \\
\text { thus, they can be deployed in locations } \\
\text { where people are not disturbed by their } \\
\text { presence. }\end{array}$ & $\begin{array}{c}\text { The public wants to influence the location } \\
\text { of the wind turbines and reap the local } \\
\text { benefits of such projects. }\end{array}$ \\
\hline Wind assessment & $\begin{array}{l}\text { Wind turbine } \\
\text { manufacturer }\end{array}$ & $\begin{array}{l}\text { Sweden is known for its trees and forest } \\
\text { industry, which means that there is plenty } \\
\text { of data supporting the growth and felling } \\
\text { of trees. Without trees, it would be } \\
\text { difficult to predict the wind conditions } \\
\text { and operational performance of the wind } \\
\text { turbines. }\end{array}$ & $\begin{array}{l}\text { The distance between the turbines and } \\
\text { the main grid can be very long in Sweden. }\end{array}$ \\
\hline
\end{tabular}

stakeholders have been anonymized, but a brief description of each stakeholder group is presented in Table 2. The interviews have been analyzed for each organization in the different groups, and as an output, the synthetic considerations of risks for the future development of onshore wind power in Sweden are listed.

The risks uncovered in the qualitative studies presented in Table 2 verify the findings from the literature review in Section 1.1 of this research paper. It becomes clear that the wind industry in Sweden is in need of a resource map which takes into consideration the need of all stakeholder groups, as they clearly all have a role to play in the future of the Swedish wind industry. The opinions from the stakeholder groups have been incorporated in the social constraints in the final sociotechnical wind atlas.

\subsection{Constructing a Sociotechnical Wind Atlas Using GIS. The} literature review identified a range of academic contributions on wind atlases for different regions of the world which will be used to structure the framework for the Swedish wind atlas.

The majority of the existing wind atlases only focus on the wind conditions and the construction of large resource maps by using different computational approaches [20-22]. Studying previous atlases confirms that the high resolution of the mesoscale dataset used in this research combined with the extensive amount of physical measurement devices 
TABLE 3: Restrictions and actions applied for the sociotechnical wind atlas.

\begin{tabular}{|c|c|c|}
\hline Restriction & Action & Why \\
\hline Roads and waterways & $\begin{array}{l}\text { A buffer radius of } 200 \text { meters has been applied for } \\
\text { further restrictions. }\end{array}$ & $\begin{array}{l}\text { A certain distance needs to be applied to roads in case a } \\
\text { wind turbine should break and/or fall. Adding roads to } \\
\text { the atlas also serves as an important feature in the } \\
\text { planning process, as the infrastructure is important in } \\
\text { the construction phase. }\end{array}$ \\
\hline Railways & $\begin{array}{l}\text { A buffer radius of } 200 \text { meters has been applied for } \\
\text { further restrictions. }\end{array}$ & $\begin{array}{l}\text { A certain distance needs to be applied to railways in } \\
\text { case a wind turbine should break and/or fall. Adding } \\
\text { railways to the atlas also serves as an important feature } \\
\text { in the planning process, as the infrastructure is } \\
\text { important in the construction phase. }\end{array}$ \\
\hline $\begin{array}{l}\text { Buildings (residential, } \\
\text { industrial, and public) }\end{array}$ & $\begin{array}{l}\text { A buffer radius of } 200 \text { meters has been applied for } \\
\text { further restrictions. }\end{array}$ & $\begin{array}{l}\text { Distances to buildings in Sweden are determined by the } \\
\text { noise and flicker emissions from wind turbines, which } \\
\text { vary from each wind project. Therefore, a radius of } 200 \\
\text { meters has been applied as a minimum distance, } \\
\text { though it might be more or less for a given site. }\end{array}$ \\
\hline $\begin{array}{l}\text { Protected buildings } \\
\text { (castles, monuments, } \\
\text { etc.) }\end{array}$ & $\begin{array}{l}\text { A buffer radius of } 200 \text { meters has been applied for } \\
\text { further restrictions. }\end{array}$ & $\begin{array}{l}\text { A distance of } 200 \text { meters has been applied to protected } \\
\text { buildings, as the decentralized Swedish political system } \\
\text { allows members of municipalities to complain about } \\
\text { new wind projects. Protected buildings have often been } \\
\text { the source of such complaints in international public } \\
\text { inquiries [19]. }\end{array}$ \\
\hline $\begin{array}{l}\text { Protected areas (Natura } \\
2000 \text { ) }\end{array}$ & $\begin{array}{l}\text { No buffer radius has been applied, only the area } \\
\text { itself. }\end{array}$ & $\begin{array}{l}\text { According to the stakeholder analysis, it was important } \\
\text { to avoid wind turbines in scenic areas, which are often } \\
\text { restricted from any building projects. Sweden has } \\
\text { several areas that are protected due to various reasons, } \\
\text { such as rare bird species, large population of wildlife, } \\
\text { certain tree types, etc. }\end{array}$ \\
\hline Lakes & $\begin{array}{l}\text { No buffer radius has been applied, only the area } \\
\text { itself. }\end{array}$ & $\begin{array}{l}\text { Despite the fact that not all Swedish lakes are protected } \\
\text { areas, this part has been considered a restriction due to } \\
\text { the fact that installation of wind turbines in lakes would } \\
\text { require offshore wind turbines and foundations, which } \\
\text { are costlier than their onshore counterparts. }\end{array}$ \\
\hline
\end{tabular}

creates a strong data foundation compared with the previous studies. More applicable to this study are previous examples of GIS-based wind atlases, which include more parameters than the wind conditions. Such atlases have been developed all over the world $[21,22]$ and provide an extra dimension to the existing resource maps. An ambitious study also examined the proper locations for wind turbines in Sweden using GIS software by combining mesoscale wind data with environmental considerations. This study, however, did not use an extensive amount of detailed wind data from physical measurement devices, and neither did it investigate social opposition and the potential threat of such or the perceptions of the major stakeholders in the Swedish wind industry. The work of Noorollahi et al. (2016) [18] furthermore classified areas for wind farm suitability by weighting the amount of protected areas against the wind conditions. It has therefore been decided to follow some of the same principles for this research, implying that some restrictions for wind turbine development have been taken into account. The restrictions and the actions performed are presented in Table 3.

Even though this is not considered a restriction, we also considered applying restriction areas for existing operating wind turbines, as repowering of the existing wind farms will be a future option. The same goes for areas of national interest, as [23] indicated that national interests do not result in actual restrictions due to the lack of strong political definitions and tools for defining these areas.

The geodetic agencies have made many of their data publicly available in a common vector data format. The Swedish County Administrative Board (Länsstyrelsen), for example, has hundreds of shape layers divided into national and county data available for download on its website [24]. The social and environmental constraints found in this database were used to construct the restriction layer. As another data source, the open street map foundation was used to incorporate infrastructure data of Sweden. Shape files of buildings, streets, railways, and waterways as well as other bodies of water such as lakes and reservoirs were acquired from the German geodata portal, "Geofabrik" [19]. The restrictions were applied following the research design summarized in Figure 3, which introduces the three steps of the geoprocessing methodology.

The first step is the merging of the resource map based on the physical measurements provided by the wind industry and the WeatherTech wind atlas. The second step consists 


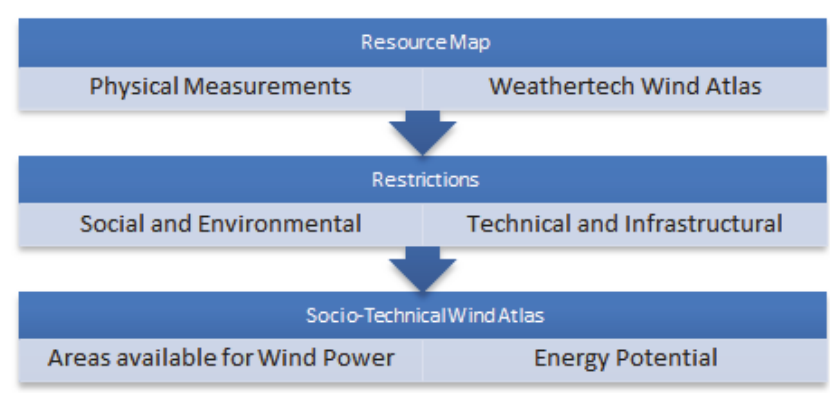

FIGURE 3: Research design for the sociotechnical wind atlas.

in merging the social and environmental restrictions and the technical limitations of buildings, and the third step involves the overlay of these to highlight the areas available for wind energy farming and show their energy potentials. In conducting these steps, different tools were used. In the first step, the wind resource map from WeatherTech had to be merged with the physical measurements. The wind resource map was downloaded in .txt format and imported in QGIS as a shapefile point layer. Since the txt file was derived from a raster file, the output points from this step were arranged in a $500 \times 500 \mathrm{~m}$ grid. These two shapefiles could easily be merged together with no further intermediate step. However, this would result in an issue where points show different wind speeds for the same area, but since there are no real overlapping points, it is technically not possible to simply replace the points. To deal with this issue, the affected points from the WeatherTech atlas were intersected by a $500 \mathrm{~m}$ buffer around the physical measurements, ensuring that no wind atlas point was closer to a physical measurement point than the normal grid distance. Subsequently, the resulting point layer was transformed into a raster file to ensure a comprehensive coverage of the whole area of Sweden. These steps were conducted using QGIS. In the second step, a large amount of data had to be managed. The downloading, organizing, and merging of the various layers were performed using ArcGIS. The layers to be merged were downloaded in polygon shapefile format and then organized into social and environmental restrictions as well as technical and infrastructural restrictions. Since most of the layers for the social and environmental restrictions were already in a suitable format, no further actions were needed. Some of the infrastructural restrictions required the intermediate step of calculating buffer zones around the road, railway, and waterway network of Sweden, since they were provided in a line shapefile format. The buffer zones show the building restrictions on each side of these infrastructural features and were determined to be $200 \mathrm{~m}$. The same distance was also applied to buildings and waterways. The resulting layer shows all social and environmental restrictions as well as all technical and infrastructural restrictions. The third and last step was to combine these two layers into one map. The map shows the two layers as an overlay by using the transparency functionality and adding other geographical items such as legend and scale in the print composer of QGIS.

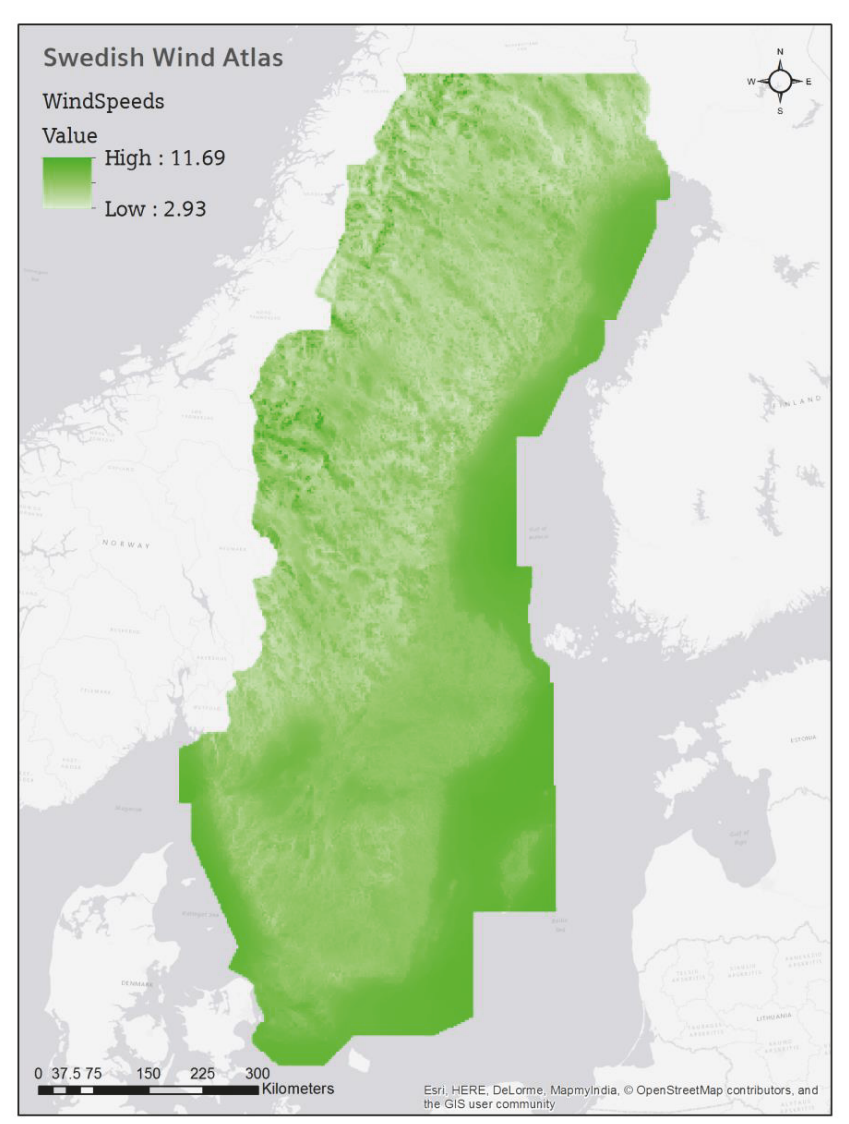

FIGURE 4: The combined wind resource map.

\section{Results and Discussion}

This section presents the results for the Swedish sociotechnical wind atlas by analyzing and introducing (1) the wind resource map, (2) the map of restrictions, and lastly (3) the final sociotechnical wind atlas.

3.1. The Wind Resource Map. A vital part of this research is the wind conditions, and the map in Figure 4 displays the Swedish wind speeds based on an updated wind atlas consisting of data from the physical measurement devices and the wind atlas from WeatherTech.

When examining the visual impacts shown on the map, it becomes clear that the areas with the highest wind speeds are along the coasts and in the southern and southeastern part of Sweden, i.e., areas with high population densities. In these areas, cabling and transport costs can be reduced; however, most likely, these areas also have the most restrictions. As visualized on the map, the wind speeds are also high in some parts of the mountains separating Sweden from Norway, but this area has not been found suitable for wind turbines due to expected additional installation costs and lack of infrastructure.

3.2. Mapping the Restrictions. Figures 5-7 display the restriction layers, which were compiled after merging layers and calculating buffer zones, added on top of the wind resource map. 


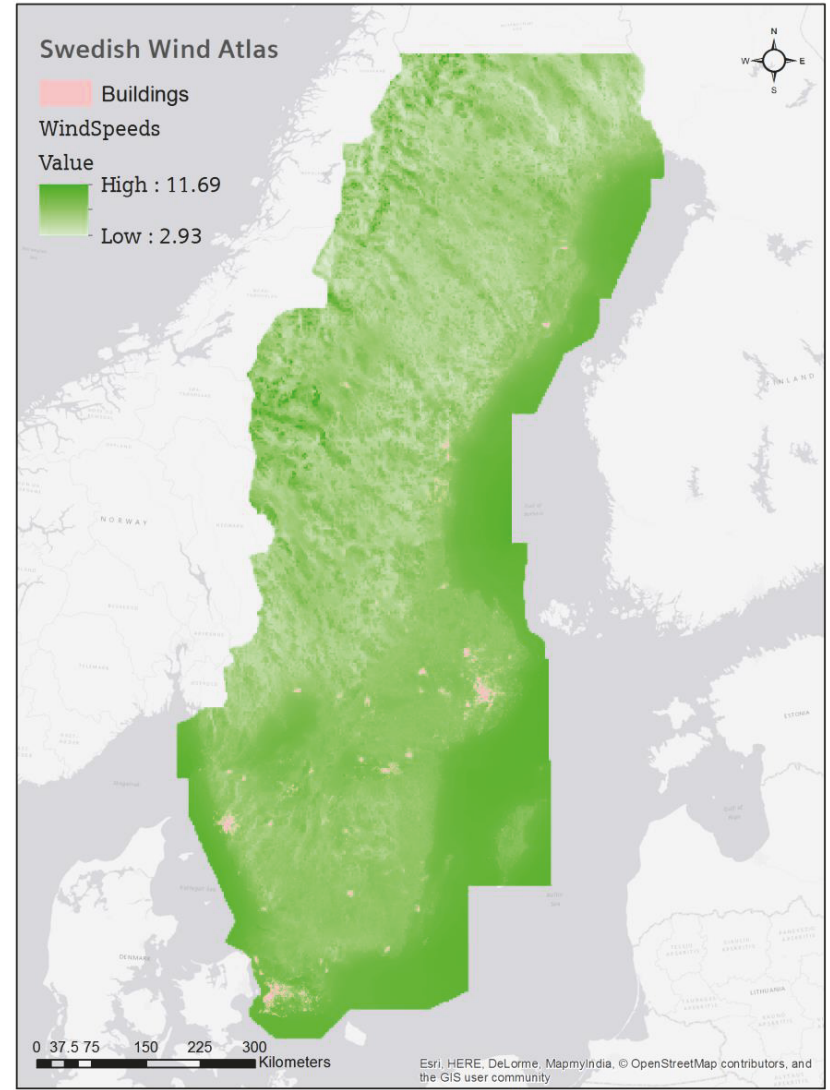

FIGURE 5: Restrictions based on buildings.

The restrictions presented in Table 3 have been combined into three overall restriction groups: (1) buildings, (2) national and natural constraints, and (3) infrastructure.

As of January 2016, the population of Sweden was 9,822,093 people [25], which equals a population density of 21.8 persons per $\mathrm{km}^{2}$. The total area is $450,295 \mathrm{~km}^{2}$. This is a relatively small population density, and the building restrictions, which also include industrial and public buildings, are therefore not one of the major impediments to future wind project development. The restrictions related to buildings are illustrated by the pink dots in Figure 5.

The area covered by buildings, including buffer zones, was calculated to be $12,845 \mathrm{~km}^{2}$. Sweden has several national constraints designed to conserve heritage buildings and areas, protected natural areas, and protected wildlife. The restrictions are more extensive than the buildings shown in Figure 6, where the national and natural constraints are added to the building restrictions. These constraints also cover potential offshore wind project development. The offshore area, however, has not been taken into account in this research but has been kept for informative purposes.

The area of the environmental constraints was determined to be $197,944 \mathrm{~km}^{2}$, which only includes the onshore constraints. In addition, Sweden has an area of $240,649 \mathrm{~km}^{2}$ that is subject to social and environmental constraints, including areas of tourism, cultural heritage, and the results from the qualitative studies presented in Table 1. Naturally,

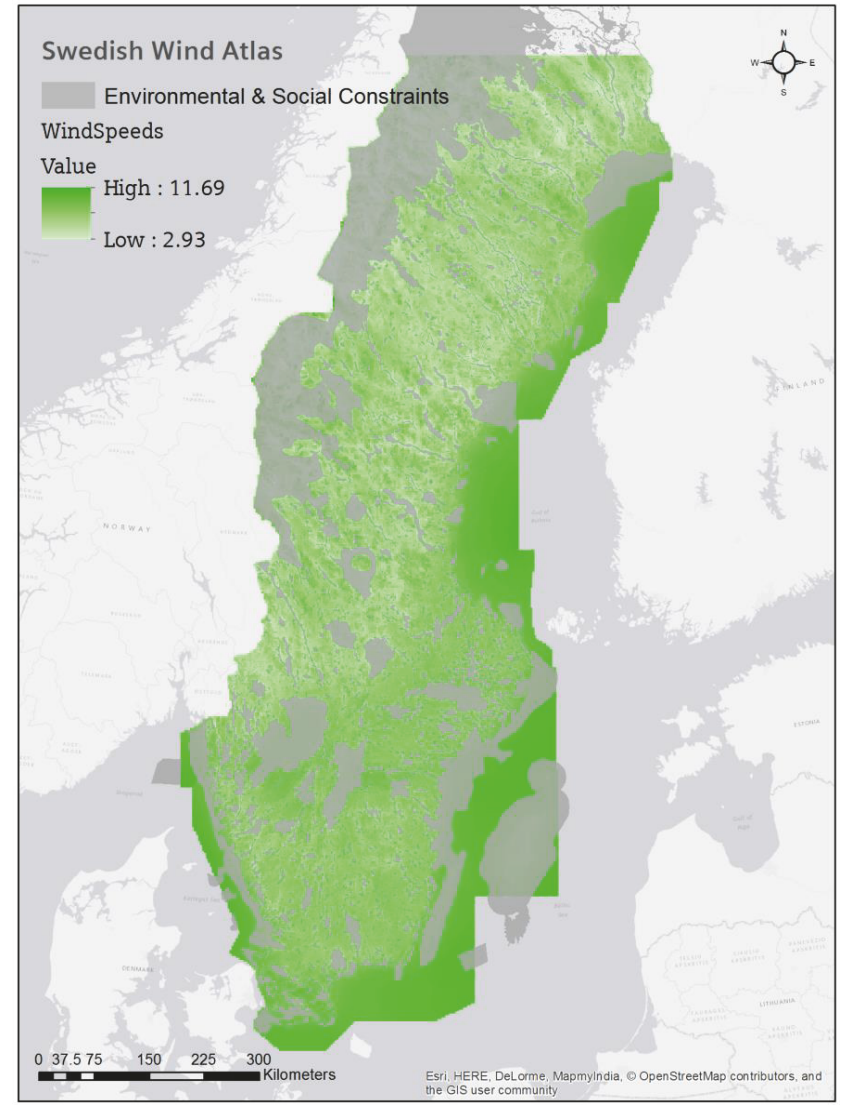

Figure 6: National and natural restrictions.

these two categories have a great deal of overlap, which has been taken into account in Figure 8. The third and final group of restrictions constitutes the infrastructure of Sweden, including roads, railways, and waterways, adding up to $160,206 \mathrm{~km}^{2}$. These restrictions have overlaps with the ones presented in the two previous groups. The result presented in Figure 7 shows that especially the southern part of Sweden has large areas covered by infrastructure, making it harder to find land for onshore wind projects. This regional heterogeneity in Sweden has previously been discussed by [23] and is further verified by this study. The study furthermore addresses the risks associated with wind project development and maps several of the risks presented by [26]. At the same time, this map represents all restrictions combined, which from a zoomed-out perspective does not leave much hope for future onshore wind project development in Sweden.

Therefore, analyses using GIS software have been carried out to determine the areas where wind turbines can be constructed legally.

As illustrated in Figure 7, several restrictions are overlapping, why simply adding the area of each restriction would produce a faulty conclusion as to the areas suitable for wind project development. Consequently, a calculation of the area has been performed using a three-step procedure. First, the restrictions and the land border of Sweden have been rasterized in a $10 \times 10 \mathrm{~m}$ grid using GIS; the value of the border grid is 1 in each cell which lies within the borders of Sweden, 
TABLE 4: Two scenarios for wind turbine potential in Sweden anno 2018.

\begin{tabular}{lcc}
\hline Area $\left(\mathbf{k m}^{\mathbf{2}}\right)$ & Rotor diameter/spacing horizontal distance (meters) & Number of wind turbines in Sweden \\
\hline 0.157 & $3.45 / 448.5$ & 973,180 \\
\hline 0.372 & $5.3 / 689$ & 410,724 \\
\hline
\end{tabular}

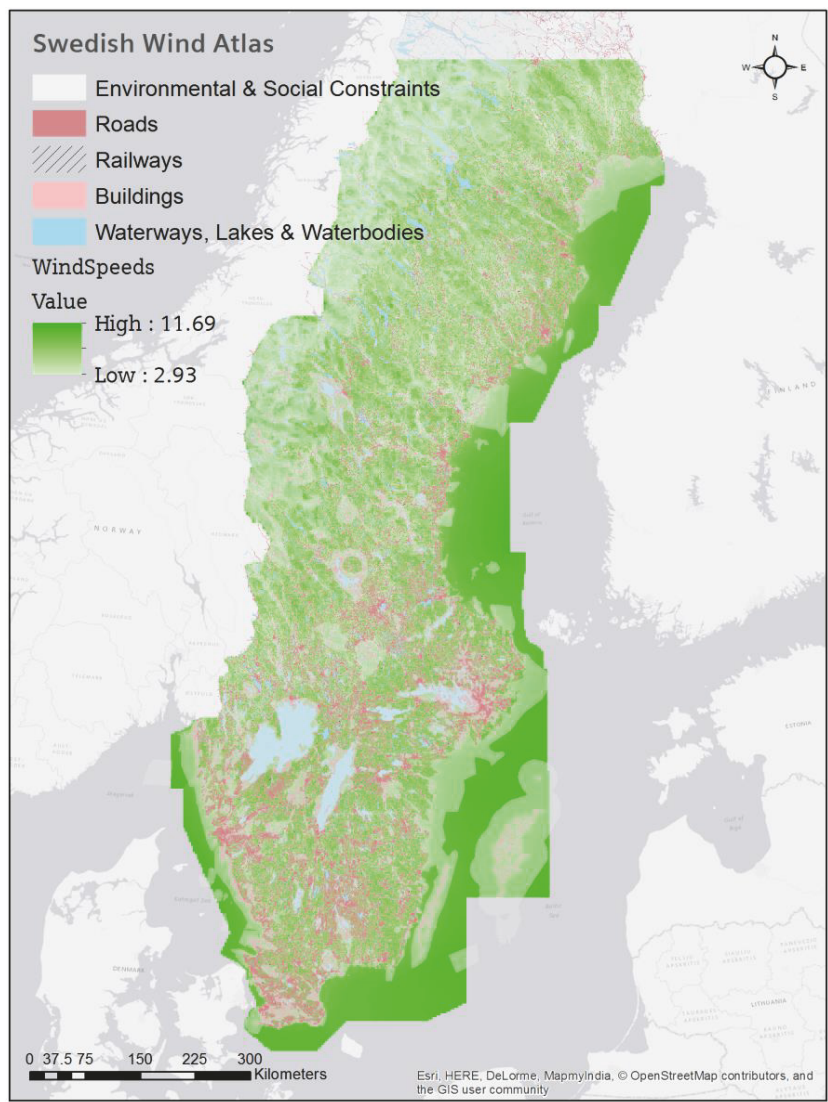

FIGURE 7: Adding infrastructure.

and each cell of the restriction layers is 1 where there happens to be a restricted area or other feature present. Second, the resulting raster files have been subtracted from the border layer in this form

$$
\begin{aligned}
\text { Output }= & \text { border Sweden } \\
& - \text { environmental and social constraints } \\
& - \text { infrastructure. }
\end{aligned}
$$

Third, the resulting number of cells has been calculated and multiplied by the respective area of each pixel to get an indicative size of the area in square kilometers. Figure 8 presents the area of Sweden covered by restrictions, and Figure 9 shows the remaining land left for wind project development.

The analysis' results indicated in Figure 9 suggest that Sweden has $152,789 \mathrm{~km}^{2}$ left for wind project development. Figure 10 shows that the restrictions for Sweden are almost equally divided between Environmental and Social constraints and Technical constraints. Accordingly, it is possible to determine the number of wind turbines that can potentially be installed in Sweden. With the increasing size of wind turbines, it seems fair to use a rotor diameter of 130 meters to estimate the potential number of onshore wind turbines that can be installed across Sweden. The actual footprint of a wind turbine is only a few square meters, but of course it needs more land to avoid wake effects. We have estimated two scenarios with different spacing distances between wind turbines. The scenarios are based on a recent study that revealed the median minimum (3.45 times the rotor diameter) and median maximum (5.3 times the rotor diameter) spacing of more than 500 wind turbines located in onshore rural unforested areas and in onshore forested areas [1]; the results of that study seems to fit with the Swedish landscape. The spacing between the selected wind turbine types has been estimated as follows:

$$
\begin{aligned}
\mathrm{A} & =\pi \cdot \mathrm{r}^{2}=\pi \cdot(1.725 \cdot 130 \mathrm{~m})^{2} \approx \times 157,904 \mathrm{~m}^{2} \\
\text { and } \mathrm{A} & =\pi \cdot \mathrm{r}^{2}=\pi \cdot(2.65 \cdot 130 \mathrm{~m})^{2} \approx 372,655 \mathrm{~m}^{2}
\end{aligned}
$$

The area requirements of a single wind turbine have been used to determine the potential number of wind turbines in Sweden for the two scenarios by dividing it with the national unrestricted area. The results are presented in Table 4 .

The number of wind turbines presented is only a theoretical estimate. Nonetheless, it reveals that there are opportunities for Sweden to continue its positive development of installed wind power capacity. Another study suggested an average spacing distance equaling a land use area of $0.78 \mathrm{~km}^{2}$ [27], which would equal 195,884 wind turbines with a rotor diameter of 130 meters. However, since this particular study also included offshore wind turbines, it has not been taken into consideration.

3.3. Practical Appliance. The sociotechnical wind atlas provides several analysis opportunities, including the enormous onshore wind power potential for Sweden exposed in this paper. Table 5 introduces additional practical opportunities using the sociotechnical wind atlas for wind power purposes.

\section{Conclusion}

A mix of quantitative and qualitative data has resulted in the first countrywide sociotechnical wind atlas. The methodology applied in this research is considered applicable for any country, and since OSM data is available in many countries, the stakeholder interviews can be conducted in any country. However, the wind data is considered unique for Sweden, both in terms of the wind atlas provided by WeatherTech 


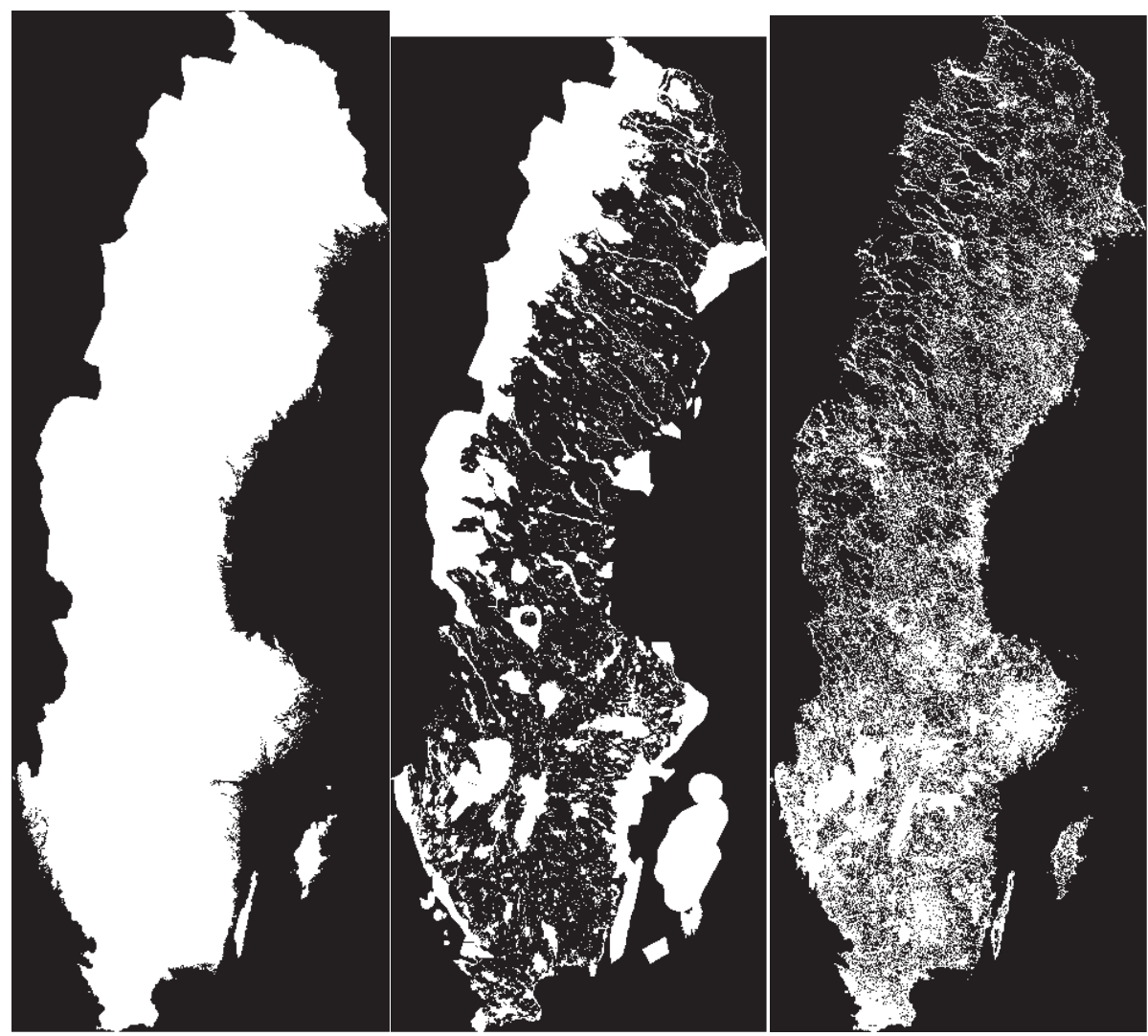

FIGURE 8: Rasterizing the constraints.

TABLE 5: Practical appliance and impact of the sociotechnical wind atlas.

\begin{tabular}{ll}
\hline Practical appliance & Explanation \\
\hline Wind resource assessment & $\begin{array}{l}\text { The socio-technical wind atlas includes a wind atlas with a spatial resolution of 500. Since the mean } \\
\text { difference between the measured wind speeds and the wind atlas was 5.4\%, the atlas is considered } \\
\text { usable for (a) selecting regions with promising wind speeds and (b) using the high resolution to } \\
\text { perform wind studies before installing a physical measurement device. }\end{array}$ \\
\hline Logistic planning & $\begin{array}{l}\text { The deployment of wind farms often includes infrastructural changes such as construction of roads. By } \\
\text { using the socio-technical wind atlas, it is possible to utilize the existing road network, and, more } \\
\text { importantly, to gain information about protected natural areas where approvals are required before } \\
\text { potential deforestation. }\end{array}$ \\
\hline Energy policy & $\begin{array}{l}\text { The development of Swedish wind power planning is very much dependent on a decentralized energy } \\
\text { policy with municipalities impacting the decision on whether to implement a wind project or not. By } \\
\text { introducing the socio-technical wind atlas, municipalities and policymakers will have a tool to get an } \\
\text { overview of the potentials in a specific region. }\end{array}$ \\
\hline Tndustrial focus areas & $\begin{array}{l}\text { The wind industry can gain insight into areas of specific interest in order to plan construction of } \\
\text { factories, harbors, etc. This would naturally be a consequence of a national decision on specific areas for } \\
\text { wind project development. }\end{array}$ \\
\hline
\end{tabular}

as well as the extensive number of physical measurement devices which are considered a tremendous strength of the introduced wind atlas. The combination of the superior wind atlas and the extensive qualitative measures included in the current research enables the stakeholders of the Swedish wind industry to use and implement the findings. The results of the research further indicate that Sweden still has plenty of space remaining for wind turbines. Thus, this cannot be the explanation for the recent decrease in the country's annually installed wind power capacity. As a concluding remark, Sweden indeed has the potential to become a worldleading wind market.

\section{Data Availability}

The data used to support the findings of this study are available from the corresponding author upon request. 


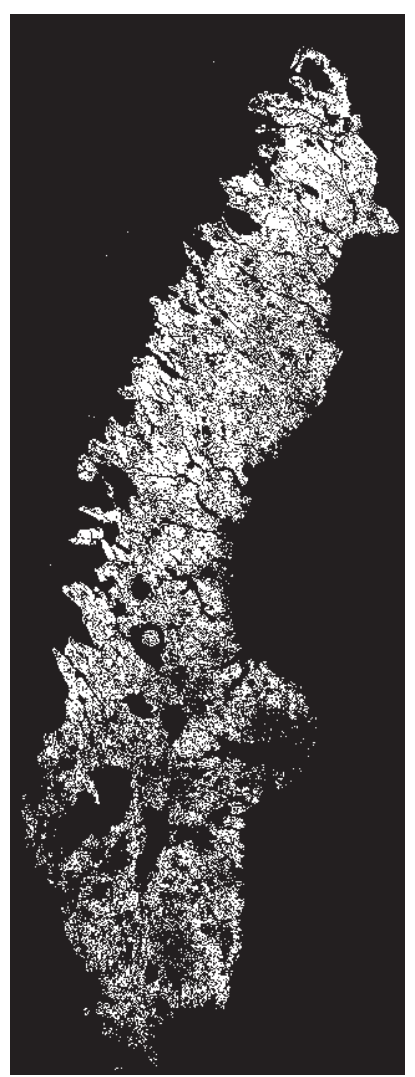

FIGURE 9: Remaining area for wind project development.

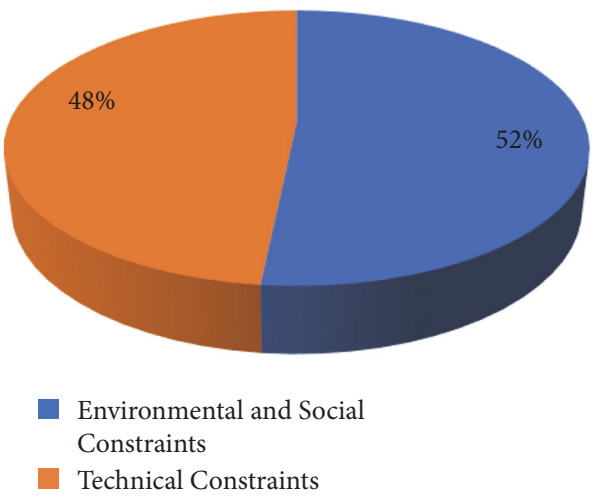

FIGURE 10: Statistics of the remaining area.

\section{Disclosure}

Any opinions, findings, and conclusions or recommendations expressed in this material are those of the authors only.

\section{Conflicts of Interest}

The authors declare that they have no conflicts of interest.

\section{Acknowledgments}

The authors are appreciative to the Department of Earth Sciences, Program for Air, Water and Landscape Sciences, Meteorologisk information, Uppsala University, and WeatherTech Scandinavia AB for giving them the opportunity to use wind data from their excellent wind atlas of Sweden.

\section{References}

[1] P. Enevoldsen and S. V. Valentine, "Do onshore and offshore wind farm development patterns differ?" Energy for Sustainable Development, vol. 35, pp. 41-51, 2016.

[2] P. Enevoldsen, S. V. Valentine, and B. K. Sovacool, "Insights into wind sites: critically assessing the innovation, cost, and performance dynamics of global wind energy development," Energy Policy, vol. 120, pp. 1-7, 2018.

[3] A. Bergek and S. Jacobsson, "Are tradable green certificates a cost-efficient policy driving technical change or a rentgenerating machine? Lessons from Sweden 2003-2008," Energy Policy, vol. 38, no. 3, pp. 1255-1271, 2010.

[4] The Wind Power Net, 2016, [Accessed 2016], http://www.thewindpower.net/country_en_17_sweden.php.

[5] N. I. Meyer, "Learning from wind energy policy in the EU: lessons from Denmark, Sweden, and Spain," Environmental Sciences Europe, vol. 17, no. 5, pp. 347-362, 2007.

[6] I. Carlman, "Wind power in Denmark! Wind power in Sweden?" Journal of Wind Engineering \& Industrial Aerodynamics, vol. 27, no. 1-3, pp. 337-345, 1988.

[7] P. Enevoldsen and B. K. Sovacool, "Examining the social acceptance of wind energy: practical guidelines for onshore wind project development in France," Renewable \& Sustainable Energy Reviews, vol. 53, pp. 178-184, 2016.

[8] M. Pettersson, Renewable Energy Development and the Function of Law: A Comparative Study of Legal Rules Related to the Planning, Installation and Operation of Windmills, Luleå University, Luleå, Sweden, 2008.

[9] M. Pettersson, E. K. Kristina, K. Söderholm, and P. Söderholm, "Wind power planning and permitting: comparative perspectives from the nordic countries," Renewable \& Sustainable Energy Reviews, vol. 14, no. 9, pp. 3116-3123, 2010.

[10] K. Ek and L. Persson, "Wind farms - where and how to place them? A choice experiment approach to measure consumer preferences for characteristics of wind farm establishments in Sweden," Ecological Economics, vol. 105, pp. 193-203, 2014.

[11] K. Ek and S. Matti, "Valuing the local impacts of a large scale wind power establishment in northern Sweden: public and private preferences toward economic, environmental and sociocultural values," Journal of Environmental Planning and Management, vol. 58, no. 8, pp. 1327-1345, 2015.

[12] T. Ejdemo and P. Söderholm, "Wind power, regional development and benefit-sharing: the case of Northern Sweden," Renewable \& Sustainable Energy Reviews, vol. 47, pp. 476-485, 2015.

[13] P. Enevoldsen, "Onshore wind energy in Northern European forests: reviewing the risks," Renewable \& Sustainable Energy Reviews, vol. 60, pp. 1251-1262, 2016.

[14] J. Anshelm and H. Simon, "Power production and environmental opinions-environmentally motivated resistance to wind power in Sweden," Renewable \& Sustainable Energy Reviews, vol. 57, pp. 1545-1555, 2016. 
[15] J. Szarka, "Why is there no wind rush in France?" Environmental Sciences Europe, vol. 17, no. 5, pp. 321-333, 2007.

[16] Swedish Forest Agency, "Swedish Statistical Yearbook of Forestry 2014," Skogsstyrelsen - Swedish Forest Agency, Jönköping, 2014.

[17] P. Enevoldsen, B. K. Sovacool, and T. Tambo, "Collaborate, involve, or defend? A critical stakeholder assessment and strategy for the Danish hydrogen electrolysis industry," International Journal of Hydrogen Energy, vol. 39, no. 36, pp. 20879-20887, 2014.

[18] Y. Noorollahi, H. Yousefi, and M. Mohammadi, "Multi-criteria decision support system for wind farm site selection using GIS," Sustainable Energy Technologies and Assessments, vol. 13, pp. 3850, 2016.

[19] Geofabrik, 2016, [Accessed 2016], http://www.geofabrik.de.

[20] C. R. Warren and M. McFadyen, "Does community ownership affect public attitudes to wind energy? A case study from southwest Scotland," Land Use Policy, vol. 27, no. 2, pp. 204-213, 2010.

[21] P. Enevoldsen, "Wind power in forested areas: determining the roughness length and displacement height for coniferous trees," in AWEA, New Orleans, LA, USA, 2016.

[22] P. Enevoldsen, "A socio-technical framework for examining the consequences of deforestation: a case study of wind project development in Northern Europe," Energy Policy, vol. 115, pp. 138-147, 2018.

[23] T. Lauf, K. Ek, E. Gawel, P. Lehmann, and P. Söderholm, The Regional Heterogeneity of Wind Power Deployment: An Empirical Investigation of Land-use Policies in Germany and Sweden, Helmholtz-Zentrum für Umweltforschung GmbH-UFZ, Leipzig, Germany, 2018.

[24] Länsstyrelsen, 2016, [Accessed 2016], http://www.lansstyrelsen .se.

[25] Countrymeters, 2016, [Accessed 2016], http://www.countrymeters.info/en/Sweden.

[26] P. Enevoldsen, Managing the Risks of Wind Farms in Forested Areas: Design Principles for Northern Europe, Department of Business Development and Technology (BTECH), Aarhus University, 2017.

[27] M. A. Delucchi, M. Z. Jacobson, Z. A. F. Bauer, S. Goodman, and W. Chapman, "Spreadsheets for 139-country $100 \%$ wind, water, and solar roadmaps," 2016, [Accessed 2016], http://web. stanford.edu/group/efmh/jacobson/Articles/I/WWS-50-USStateplans.html. 

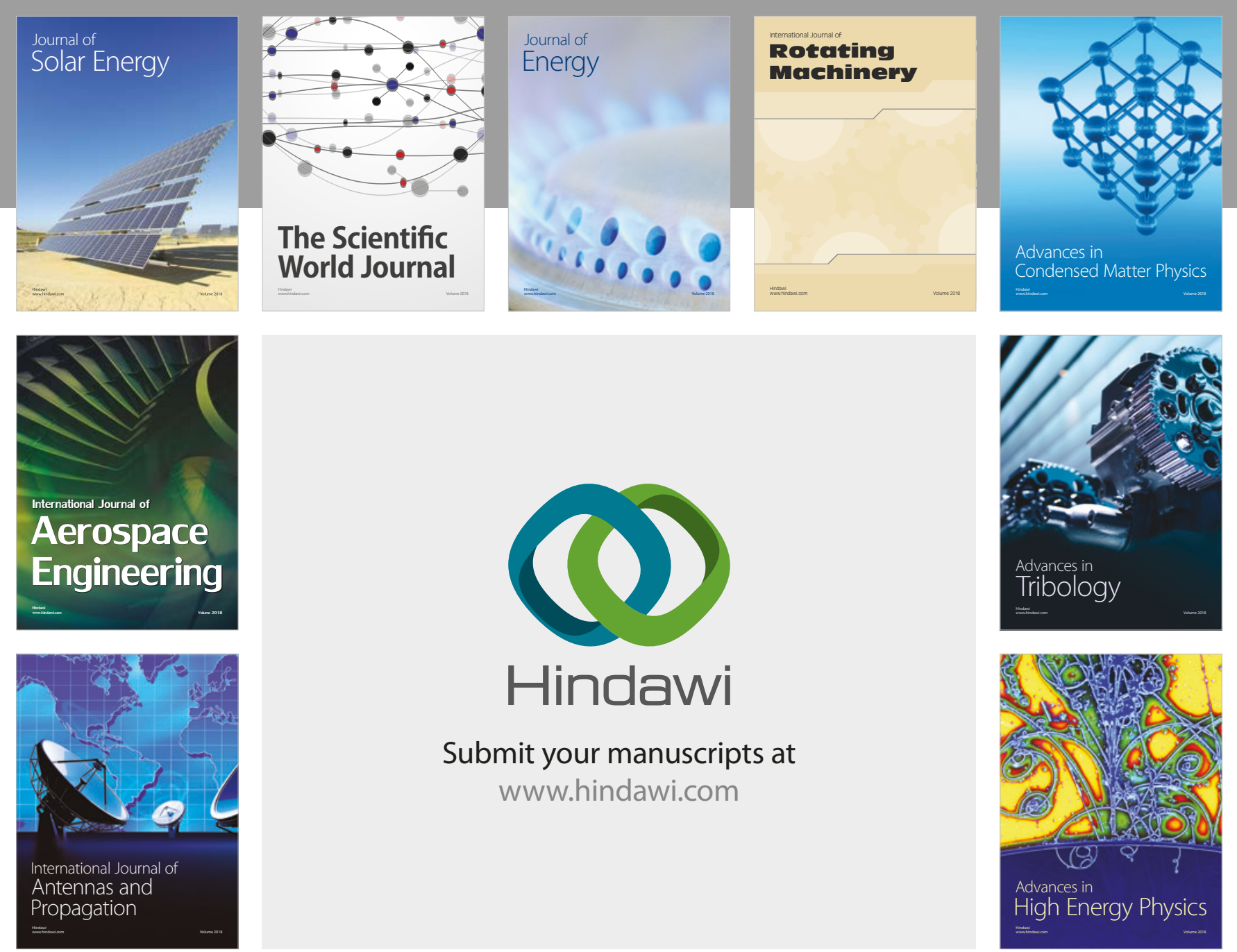

Submit your manuscripts at

www.hindawi.com
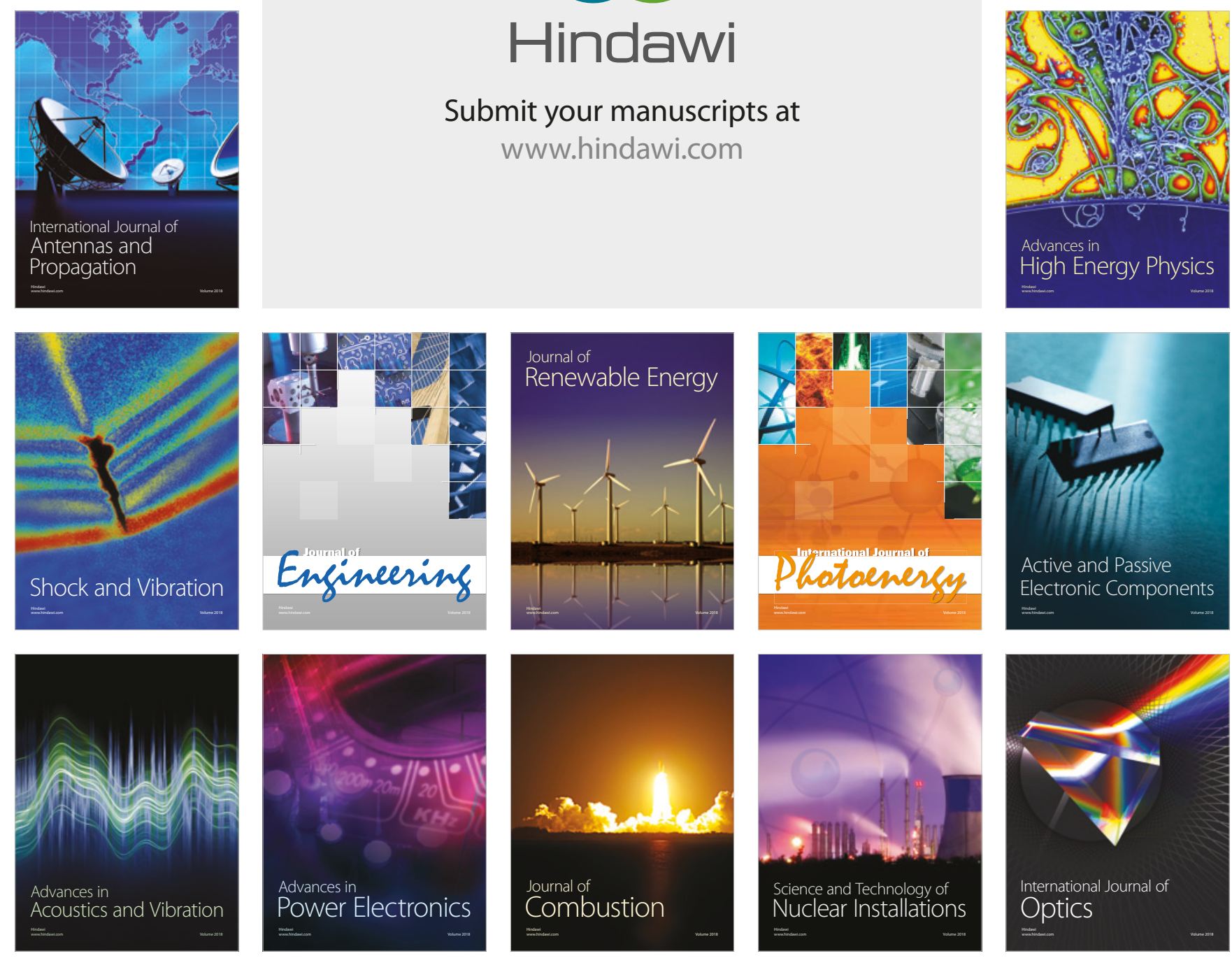